\title{
The Status of Forest Ecosystem Services and Their Management: The Case of Uzigua Forest Reserve in Tanzanian Coastal Forests
}

\author{
Elly Josephat Ligate ${ }^{1,2, *}$, Shen-Zeng $\mathrm{Wu}^{3}$, Can Chen ${ }^{1}$ \\ ${ }^{1}$ Department of Ecology, College of Forestry, Fujian Agriculture and Forestry University, China \\ ${ }^{2}$ Faculty of Science, Sokoine University of Agriculture, Tanzania \\ ${ }^{3}$ Department of Ecology and Resource Engineering, Wuyi University, China
}

Copyright $\bigcirc 2017$ by authors, all rights reserved. Authors agree that this article remains permanently open access under the terms of the Creative Commons Attribution License 4.0 International License

\begin{abstract}
Sustainable forest production and management require an understanding of how people identify and understand coastal forests ecosystems (CFEs) services and their management. This study was conducted to understand how local people are aware about status of coastal forest services and their implications on the current management options. We conducted a survey at Uzigua Forest Reserve in Bagamoyo district, Pwani Region-Tanzania. Interviews and questionnaires were used to cross-examine 178 respondents followed by one triangulation workshop to fine tune the findings and avoid biased responses. We found that, an understanding of a full range of services provided by coastal forests ecosystems is lacking. Although local people are aware of activities causing forest's degradation, still they don't have alternative livelihood means to sustain life independent of forest resources. These deficits are key factors that hinder efforts for management of coastal forests thus contributing to nonstop degradation of coastal forests along the coastal zone of Tanzania. Efforts are required to ensure that local people are aware about services and management benefits. We hope that these efforts will contribute to stop the loss of existing forest and mitigate impacts on the ecological services provided by these forests.
\end{abstract}

Keywords Coastal Forests, Ecosystem Services, Forest Management, Uzigua Forest Reserve, Forest Degradation

\section{Introduction}

Every kind of human civilization is connected to forest ecosystems. The intimate connection of human and forest ecosystems is emanating on the fact that forest ecosystems are providers of wood, fibers, bio-energy, species, habitat, carbon sequestration and water cycling, as well as cultural and recreational value [1]. These services are provided by forests that cover an area of 3999 Mha globally [2].This coverage is equivalent to $31 \%$ of global land area where by $44 \%$ of global forest area is found in tropical and another $8 \%$ is in sub-tropical countries [3]. Temperate countries account for $26 \%$ of global forest area and boreal countries for $22 \%$ [2] while half of the world's forest area is within sub-regions (Africa inclusive) where forest extent has been declining since 1990 [4].

The area of forest and woodlands of Tanzania mainland is 48.1 million hectares [5], while Tanzania's coastline forests cover an area of about $800 \mathrm{~km}^{2}$, stretching from latitude $4^{\circ} 49^{\prime} \mathrm{S}$ at the border with Kenya to the border with Mozambique at latitude $10^{0} 28^{\prime} \mathrm{S}$ [6]. Attitudinally, these forests are distributed from sea level to a maximum of 1100 $\mathrm{m}$ from the Indian Ocean to the base of the Eastern Arc Mountains [7]. Forests located on the coastal zone of Tanzania are important as supporters of nearly three-quarters of Tanzania's industries [8], and is home to over a quarter of the country's population [9]. The coastal forests ecosystem contains about 190 forest species, of which 92 are endemic [7]. These forests are hotspots with at least $0.5 \%$, or 1500 of the world's threatened 300000 species of vascular plants; however, they have lost at least $70 \%$ of their primary vegetation [10]. Because of the diverse plant species that make them, Tanzanian coastal forests are included as part of the 34 world biodiversity hotspots and are considered being one of Africa's most important centers of endemism [11]. Yet these forests are among the most threatened biodiversity hotspots on earth [12]. These forests face stress from the growing population, environmental degradation and the impacts of climate change [13].

Valuable previous documentation by $[5,7-14,8,10,12$, $15,16,17,18,19]$ and describe the biophysical properties, forests services and workable management options. Yet, there remains a lack of information on the understanding on 
the current status of coastal forests services and dynamics, value, drivers, threats and current opportunities and challenges for their management. Therefore this study was conducted to assess community understandings on the existing tree species and ecosystem services. The study identified the current role of different rural settings in management of coastal forests ecosystems focusing on responsibility divisions. Also in this study opportunities and current challenges on coastal forests management are analyzed. It is hoped that findings from this work will urge public and non-public forest stakeholders to undertake initiatives to encourage practical sustainable forest management in order that they continue providing valuable ecological services and goods.

\section{Materials and Methods}

\subsection{Study Area Location}

This study was conducted at Kwaruhombo and Kwang'andu villages located within $20 \mathrm{Km}$ from Uzigua Forests Reserve (UFR), which are found in Mbwewe ward (Figure.1), Bagamoyo District, Pwani region in Tanzania. This district is one of the 6 districts of the Pwani Region of Tanzania having forests reserves like Zaraninge and Uzigua. The district is bordered to the North by the Tanga Region, to the West by the Morogoro Region, to the East by the Indian Ocean and to the South by the Kibaha District. According to the 2012 Tanzania National Census, the population of the Bagamoyo District was 311740 [9].

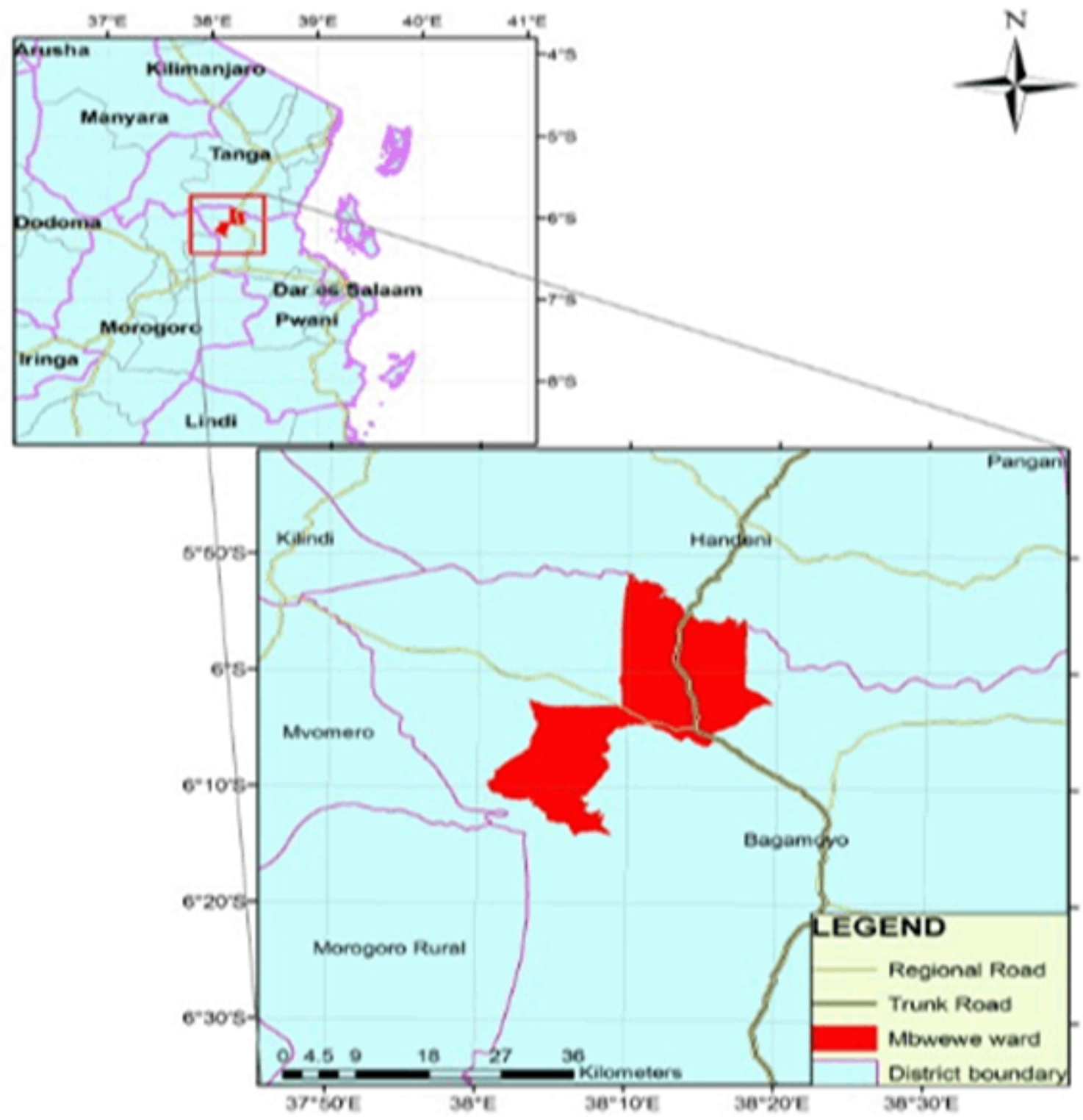

Figure 1. A map of Uzigua Forest in Mbwewe, Bagamoyo District, Tanzania) 


\subsection{Socio-economic Activities}

The main occupational activities are agriculture, livestock keeping, fishing, timber and charcoal production. Mbwewe ward was purposively chosen on the criteria that it is located within $20 \mathrm{Km}$ from UFR, which is located within $100 \mathrm{~km}$ of the Indian Ocean. The two villages were selected because they are in the perimeter of the reserve, and the two villages have village land forests. We expected that from these two villages we could learn how villagers are aware of services and management practices of forests. A cross sectional research design was employed in this study where by primary data collection took place between April and June 2016. This study was preceded with desk review of thirty eight (38) documents from different sources, including online articles as well as reports from the Ministry of Natural Resources and Tourism of the United Republic of Tanzania and Tanzania Forest Service's Agent.

\subsection{Sampling Techniques}

Both probability and non-probability sampling techniques were used to get respondents. Simple random sampling technique was used to get respondents from lists of farmers (i.e. crop producers), livestock keepers, charcoal producers and sellers, house constructors, carpenters, village security and environmental committees. Ten percent $(10 \%)$ of each small sampling frame formed a sample size. Non-probability (purposive) sampling was employed to interview two village executive officers, one ward executive officer and two district forest officers. These officers formed a key informant group category. Ten focus group discussions (five from each village) were conducted. Ten heterogeneous members formed one group whereby the composition of the group considered gender, sex, occupation and age differences. Therefore 178 people were interviewed and their responses were generalized for discussion.

\subsection{Data Collection Tools}

Data were collected by means of questionnaire and interview protocols. Discussions from spoken interviews were recorded by using audio tape recorders followed by transcription and production of memos on (i) awareness on forest ecosystem services; (ii) forests management responsibility; (iii) legal instruments for management of coastal forests (iv) long term and current activities contributing to degradation of forests; (v) opportunities and emerging challenges for current options on management of coastal forests ecosystems.

\subsection{Data Analysis}

Some of qualitative data were quantified to get statically-based output for easy interpretation while other information were used to support quantitative findings. Statistical Package for Social Science data analysis (SPSS Version 22.0) software and Microsoft excel were used to analyze socio-economic data. Tree species were identified in the field based on local people experience and forests officers' expertise, and some samples were taken to Sokoine University of Agriculture, Morogoro, Tanzania for detailed botanic identification. Prior to production of this final copy, one triangulation workshop was conducted just after partial data analysis in early July 2016 to fine tune the research findings.

\section{Results}

\subsection{Coastal Forest Tree Species Awareness}

From focus group discussions and wrap workshop, respondents identified the following coastal forest trees and the ranks were given in percentages (see Figure.2): Pterocarpus angolensis $(12 \%$ and 18\%), Brachystegia boehmii (12\% and 10\%), Brachystegia microphylla $(11 \%$ and $15 \%)$, and Acacia senegalensis (11\% and $11 \%)$. Other trees included Tamarindus indica (10\% and 10\%), Sterculia quingueloba $(10 \%$ and $10 \%)$, Xeroderis stuhimanh $(10 \%$ and $10 \%$ ), Albizia viscolar ( $8 \%$ and $12 \%$ ), Albizia petersiana, (8\% and 12\%), Screlocarya birrea (6\% and 5\%) and Terminalia catappa (6\% and 6\%) for Kwaruhombo and Kwang'andu villages respectively. 


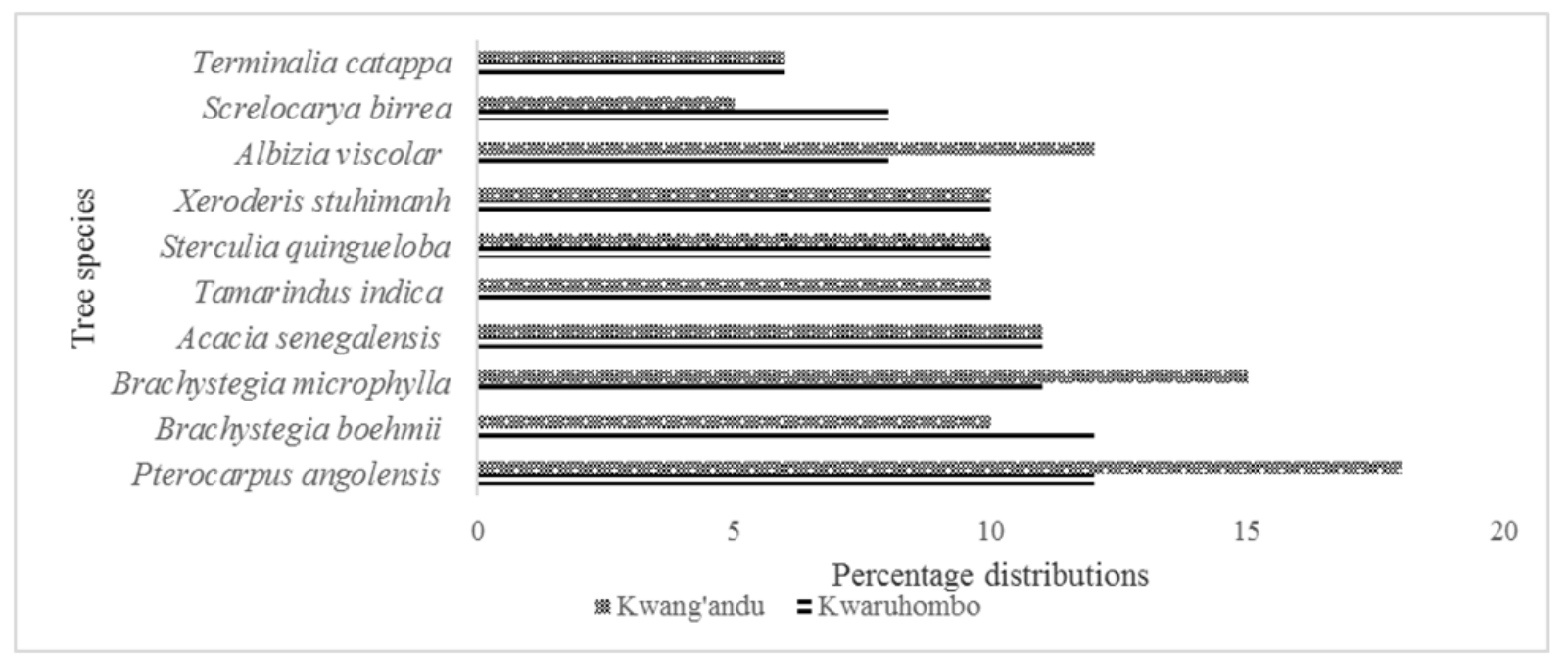

Figure 1. Listed tree species: Source: Field survey 2016

\subsection{Awareness on Coastal Forests Services and Goods}

In regards to awareness on services and goods, this study come up with the following ranks for Kwaruhombo and Kwang'andu villages respectively (see Figure. 3): About 90 by 85 stated that forests is a key player in climate regulation, while 85 by 75 people said forests are suppliers of bio energy materials (charcoal and fire woods). Eighty two (82) and ninety five (95) people said that forests provide construction materials (timber, poles and ropes) while 78 by 60 reported that forests control natural hazards (mentioning wind and soil erosion). Other services such as wildlife habitat, cultural values, forest regeneration, primary production and traditional medicines scored ranks less than 50 people across all villages.

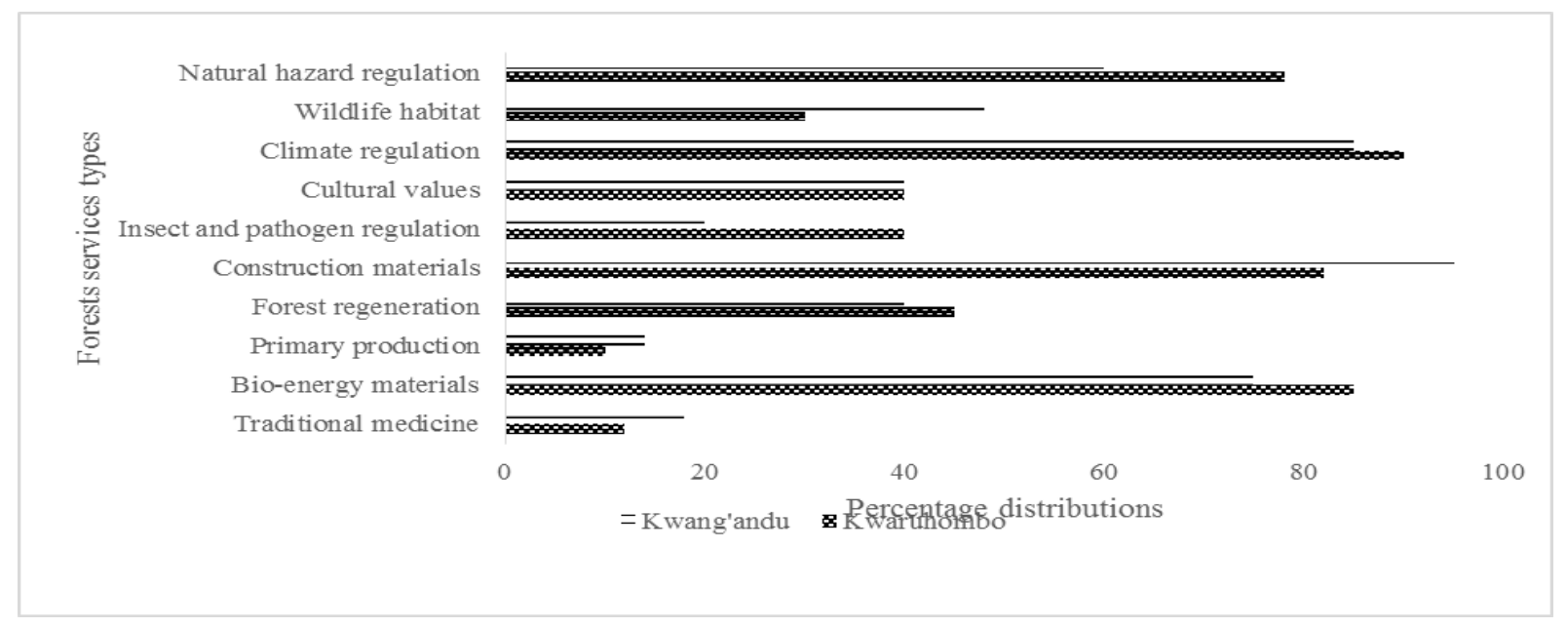

Figure 2. Coastal forest services and goods: Source: Field survey 2016

\subsection{Management Coastal Forests Ecosystems, Whose Responsibility?}

In regards to defining whose responsibility is for management of coastal forests, the following are the results for Kwaruhombo and Kwag'andu in their bracket orders (see Figure.4). About $39 \%$ by $23 \%$ pointed out management is the responsibility of local community (i.e. households), about $28 \%$ by $35 \%$ mentioned Non-Governmental Organization (NGOs) and Community Based Organizations (CBOs).Village governments were presented at $11 \%$ and $24 \%$ while about $11 \%$ by $8 \%$ reported that public and non-public employees are responsible for management of forests. 


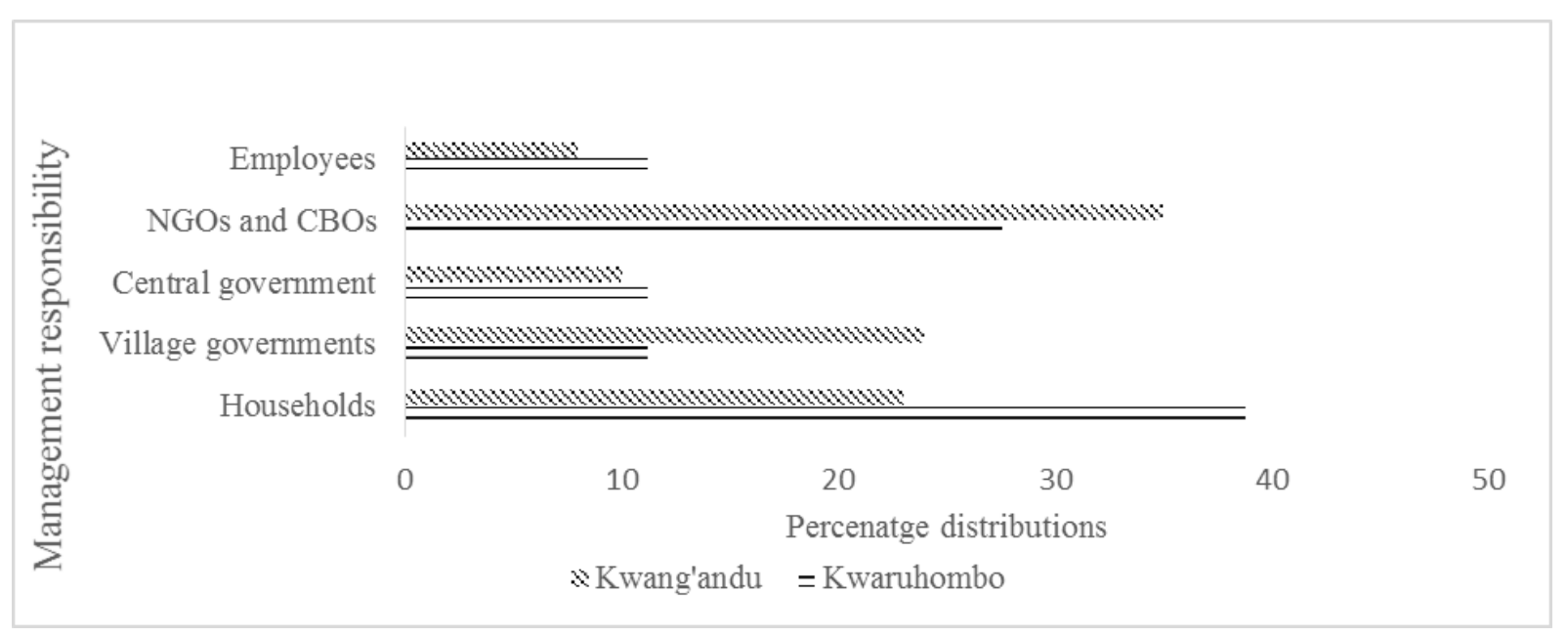

Source: Field survey 2016

Figure 3. Management of CFEs, whose responsibilities?

\subsection{Legal Instruments for Management of CFEs}

An understanding of people's awareness on the existence and application of legal instruments and tools comes out with the following results for Kwaruhombo and Kwang'andu in their respective orders (see Figure. 5): About $37 \%$ by $35 \%$ of people showed awareness that there are local village by-laws while $28 \%$ by $20 \%$ were not aware of any policy or regulation. Twenty one (21\%) by $35 \%$ showed that forests management in Tanzania is governed by policy and regulations. Only $14 \%$ by $10 \%$ showed that, although there are policies and regulations, these legal instruments are passive and that is why they are not well known.

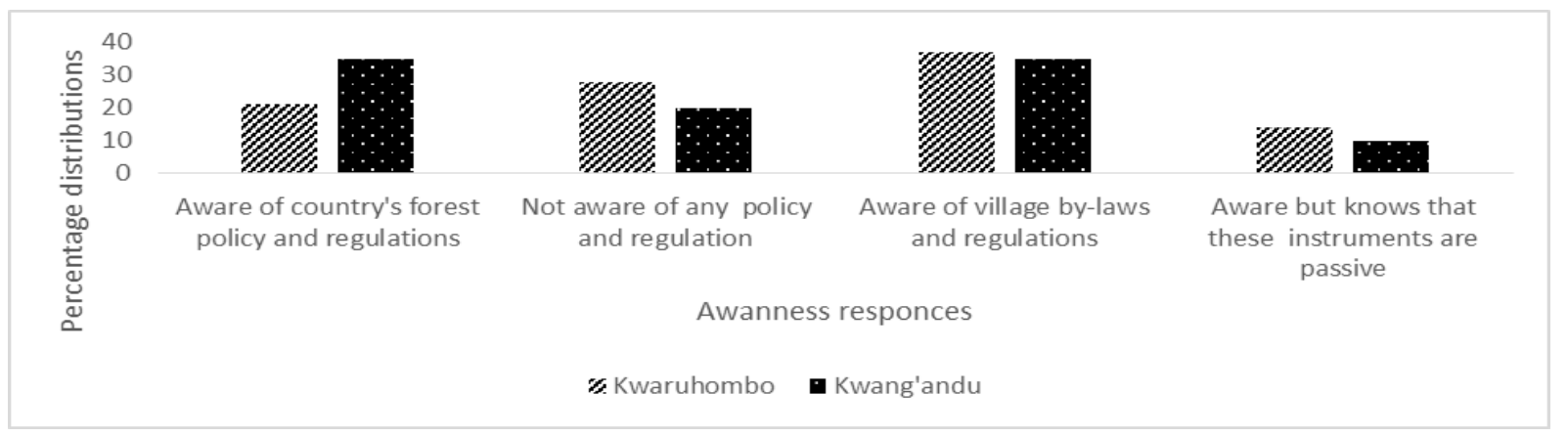

Figure 4. Awareness on policy and regulations for managing CFEs: Source: Field survey 2016

\subsection{Awareness on Activities for Loss of Coastal Forests Ecosystem Services}

The current loss of forest ecosystems in the coastal area of Tanzania are: overharvesting trees for bio-energy ( $85 \%$ by $78 \%$ ), opening new farms each season ( $75 \%$ by $87 \%$ ), and harvesting trees and fibers for construction was reported at ( $72 \%$ by $75 \%$ ) while uncontrolled fire and livestock grazing was $50 \%$ by $45 \%$ for Kwaruhombo and Kwang'andu respectively (see Figure.6). 


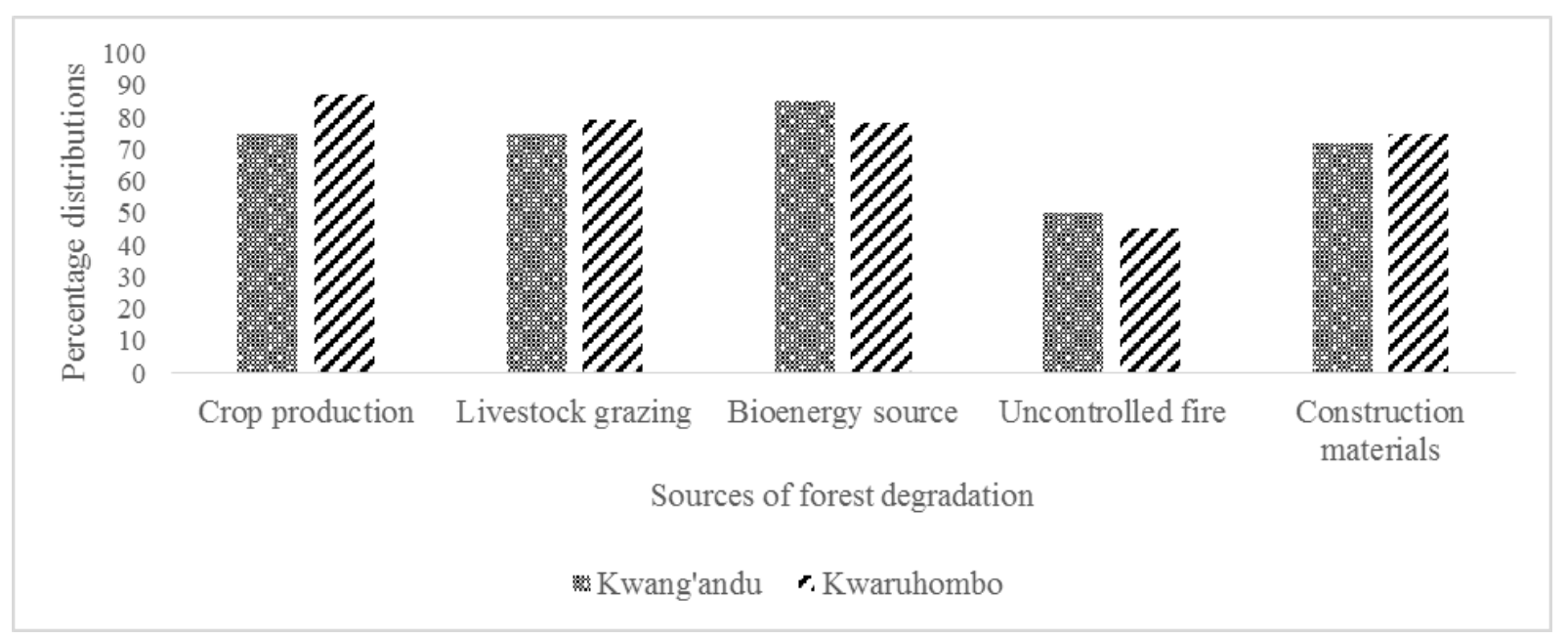

Figure 5. Activities contributing to CFEs disturbances: Source: Field survey 2016

\subsection{Available Opportunities for Managing Coastal Forests Ecosystem Services}

Results in Figure.7 show percentage distributions on available opportunities for management of coastal forest ecosystems. About $68 \%$ and $63 \%$ are willing to involve in livelihood activities, which do not depend on forests resources, about $57 \%$ by $53 \%$ of people are willing to conserve natural trees on their farms. About $50 \%$ and $67 \%$ showed that there is plenty of land for trees planting while $56 \%$ and $60 \%$ see that forest degradation can be avoided by moving into constructing houses by using earth bricks instead of forests trees poles. About $45 \%$ and $50 \%$ see that village land is available for tree planting and they are willing to plant trees on this land.

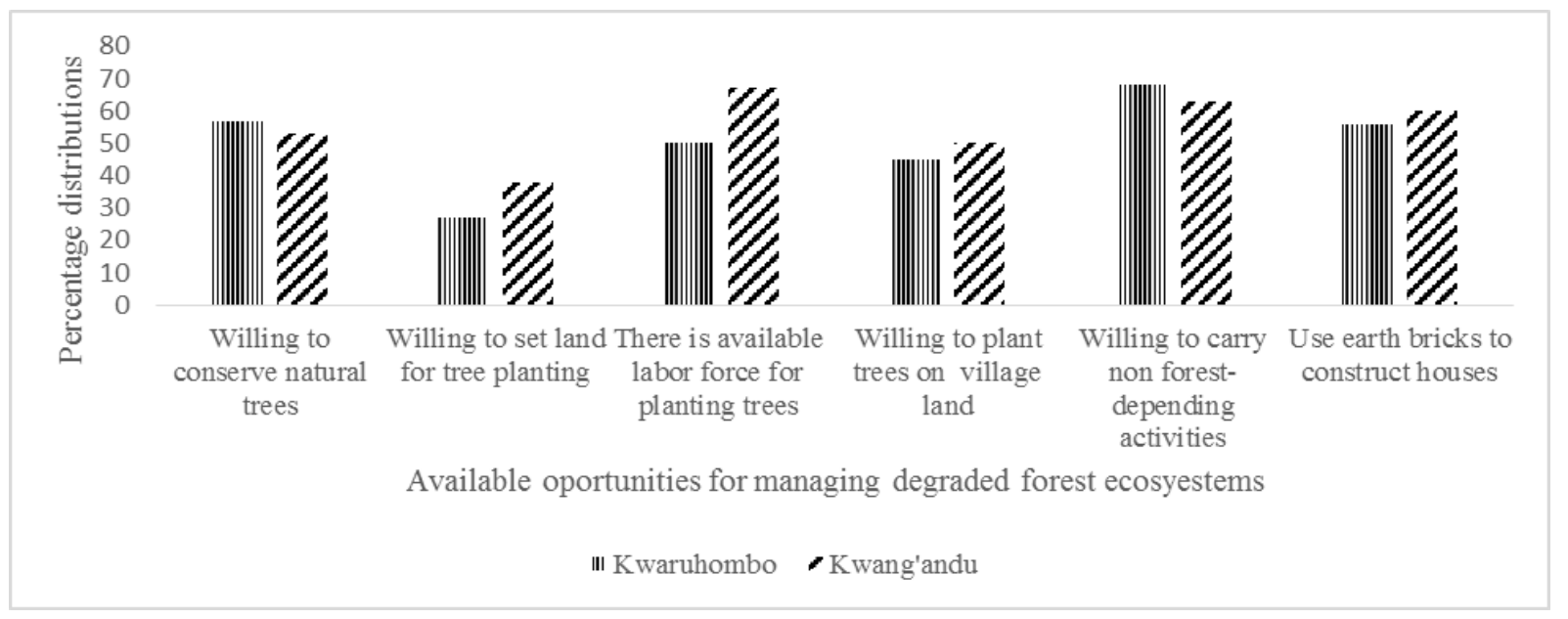

Figure 6. Opportunities to manage degraded coastal forests: Source: Field survey 2016

\subsection{Emerging Challenges on Management of Coastal Forests}

Assessment on the emerging challenge of coastal forests was as showed in Figure 8. The use of chain saws was between $70 \%$ and $89 \%$ people while $85 \%$ and $89 \%$ ranks represent motorcycle use in Kwaruhombo and Kwang'andu respectively. Fresh water scarcity and persistent food shortages were between $65 \%$ and $65 \%$, and $57 \%$ and $59 \%$ responses of people for Kwaruhombo and Kwang'andu respectively. 


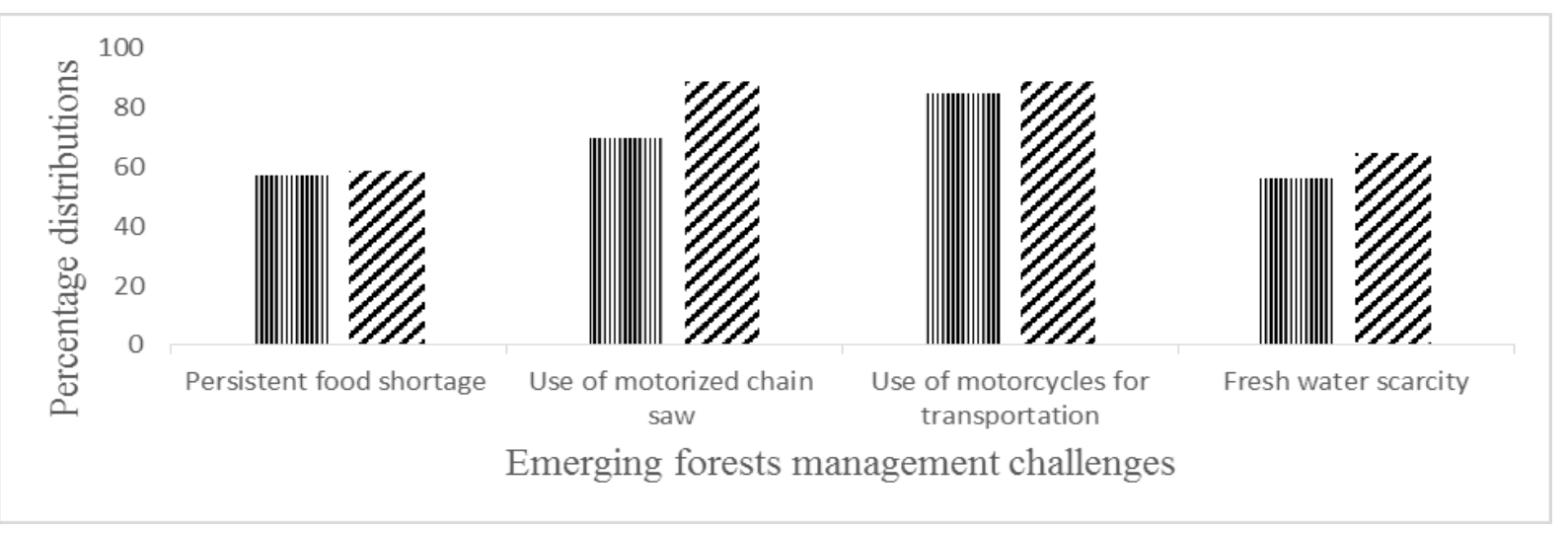

Figure 8. Emerging challenged in managing coastal forests: Source: Field survey 2016

\section{Discussion}

\subsection{Coastal Forest Tree Species Awareness}

This study discovered that people across the two villages have inadequate knowledge of tree identification, which serves only their entire life and livelihood requirements. Across the two villages, only eleven (11) (Figure.1) kinds of trees were commonly named by the majority of respondents (see Figure.1). It is found that the known trees are those which give them social-economic support rather than social-ecological functions. Trees in Figure.1 were frequently mentioned than many species listed in literature. This is a small number of trees compared with those documented by (Lovett, 2006).

Field findings revealed that there is local community information deficit regarding the kind of coastal forest tree species. This is because people easily recognize those trees which provide goods, but not those offering a set of non-tangible ecological services. In this case, those trees mentioned during the survey were frequently harvested for timber, poles, charcoal and fibers. Because of their usefulness, these trees are overharvested and are now scarce in village forests lands, with the exception of UFR where harvesting is prohibited. Yet because of the high demand for trees, people mentioned that they still illegally harvest some trees from the reserve. It is obvious that the majority of forest loss is of those trees which provide goods such as timber, charcoal and fibers. To the locals, forests management is mainly for goods contrary to findings reported by [21] that forests are managed for goods and services.

Lack of wide range recognition of forests services might be one of the reasons hindering forest management efforts because an understanding of key tree species in forest ecosystems is important as it provides information necessary for services and goods evaluation. Deficiency in information about kinds of trees and ecological value is a challenge that needs to be addressed. Awareness about trees information and ecological value is important because any effective forest management plan must address a full range of forest ecosystem present multi-functional uses and value of forests
[22]. To meet this target, it is important to put into practice the recommendations made by [23] that forest ecosystem management should establish and maintain proper records of plant status and abundance, and communicate them to stakeholders. In this case, scientific research findings need to be communicated to local community for consumption.

\subsection{Awareness on Coastal Forests Services and Goods}

Gauging and documenting about the coastal forest ecosystem services and the implications for the current management practices is important in evaluating the role of individual forests and of the entire ecosystem. Three major groups of services as per (Turner et al., 2013), were used to assess the awareness:- (i) provisioning services (timber production, bio-energy (charcoal and firewood), wildlife habitat, natural hazards, and insect and pathogen regulations), (ii) supporting services (forest regeneration and primary production) and (iii).regulation services (carbon storage). Across the villages there is a better understanding of some services now in comparison to documents by [25] For example, across all the surveyed villages and from wrap-up workshop, people were aware that forests play significant roles in climate regulation (Figure 2), which is indirectly related to issues of carbon sequestration and hydrological cycle control.

Peoples' experience of the current climate shock, expressed in terms of a lack of rainfall for consecutive three years, is connected to climate change and forests loss. This shortage contributed to create awareness on the role of forests in controlling hydrological cycle and crop production. Farmers clearly explained the association between food shortage, rainfall scarcity and forests degradation. Therefore it is certain that changes in climatic condition are a good reminder of the impacts of forest loss in the coastal region of Tanzania. It is obvious that coastal forests of Tanzania like many other forested landscapes [24] are changing rapidly and impacts are evident on social and ecological components of the community. However, there remains little attention to services such as insect and pathogen regulation, forest regeneration, primary production and natural hazards regulations. Lack of awareness about production value of 
forest is a challenge needing interventions by forest managers and other forests stakeholders [24]. There is lack of recognition of cultural values such as spiritual enrichment, cognitive development, recreation, and aesthetic experiences, which is a similar case as that reported by [26]. Therefore efforts to create awareness at community level on full range coastal forests ecosystem services is highly demanding, otherwise, if management of forests remains to focus on goods, the issue of proper management of coastal forests will continue be in jeopardy.

\subsection{Management CFEs, Whose Responsibility?}

Based on the main efforts by national and international organizations on management of coastal forests in Tanzania, types and impacts of the current forest management in villages near Uzigua Forests Reserve was assessed (see Figure.3). The current forest management approach in these two villages is Community Based Forest Management under subcategory Village Land Forest Reserve. This study found that, in Kwruhombo village, more people are willing to participate in forest management compared to Kwang'andu. One of the reasons for this willingness in Kwaruhombo is that whenever they participate in forest management activities, they receive payments between 5 000-10 000 Tanzania shillings per day, whereas at Kwang'andu, no one reported some monetary or any other kind of incentives. Under the current free market economy forest management [15], lack of incentives for sustainable forest management is a serious challenge affecting forest management as supported by [7]

It was clearly reported that because of incentives in Kwaruhombo, the village environmental committee is active and plays a good role in planning for management of forests resources than Kwang'andu although forests loss is persistent in both villages. In regards to NGOs and CBOs, in all villages there was a perception that these organizations are there not to manage forests, but fulfill their own gains under the umbrella of forests management. For example, from qualitative survey response one elderly woman in Kwaruhombo stated that let NGOs and CBOs manage forests because employees get salaries and enjoy travelling in luxurious vehicles while they leave us poor and hungry. This kind of perception is not motivating individuals to get involved in forest management activities.

This study further discovered that people perceive that NGOs and CBOs get more resource support for managing forests than individuals and or government bodies. Local people showed no understanding and recognition of how Tanzania is helped to gain access to the international development funds in forests sector through these organizations contrary to [27]. The fact that only NGO and $\mathrm{CBO}$ are active in project for management of forests is in line with the previous findings by[16], that implementation of forest management in Tanzania under different systems such as Participatory Forest Management is financially influenced more by externally funded NGOs than governments. There have been dwindling government allocations of funding for the management of resources, hence poor implementation of forest management activities [28].

Because of dwindling government support, stakeholders are heavily dependent on foreign non-governmental organizations for financial resources. That is why these organizations are active in activities for management of forests, a situation considered as the most benefiting components in the name of forests management. To create a good forests management atmosphere and allow a wide range of stakeholders to manage forests, there is a need to stick into suggestions made by [17] those governments and external actors must take advantage of already existing strategies in management of natural resources and strengthen the link between them. But what is happening under different forest management systems in Tanzania is that the interests of local governments merely lie in activities that enhance generating revenue, where by a component of environmental conservation for ecological value is not emphasized unlike the interest of NGOs and CBOs [29].Therefore, it is important to address the priorities of local interests, agencies and capacities for the successful management of forests [30] while taking into account new knowledge and understandings of social-ecological management strategies of forest resources hence making all stakeholders responsible for management of forests.

\subsection{Legal Instruments for Management of CFE}

Local community awareness of policing and other legal instruments for management of coastal forests is not promising (see Figure.4). In the study area, it was found that there is no clear setup of who is responsible to issue and monitor the application of guidelines, and as a result, documents are not available at different levels except at Districts. This challenge is hindering forest management [31]. When there are no clear guidelines, there are poor land use plans and conflict over land use for example, it was reported that there are conflicts between different land users in Mbwewe ward. Some conflicts, which were reported that are those between sectors such as crop production, livestock and forestry. Unavailability of legal instruments and lack of active systems to create awareness at village level hinders the whole array of knowing policies, laws and regulations governing forests management. The issues of passive laws and regulations are one among many challenges mentioned in this study as reported by [14] and [26]. Much is needed from public and non-public sectors to continue providing technical assistance and capacity building especially to help villagers know laws and by-laws governing forest management. It is the time for users of forests resources to be aware and comply to the rules and policies such as National Environmental Policy (1997), the National Forest Policy (1998), the Forest Act (2002) and the Environmental 
Management Act (2004) [32]. All of these instruments provide the basis for the environmental management in which coastal forests are included.

\subsection{Awareness on Activities for loss of Coastal Forests Services}

Although much has been done to manage coastal forests in Tanzania [5], yet degradation of forests is persistent and the reasons for degradation since early 1980s are documented as small-scale agricultural expansion, introduction of large-scale agriculture, human settlements and population increase [5]. In this study it is reported that expansion for agricultural land is more severe now than before as also founded by [33]. In the study area farmers reported that production per unit area is currently low because of climate change impacts. To adapt for these changes farmers expand agriculture activities into forests to compensate for the low production as supported by [34], hence increased deforestation and degradation. Another activity resorted to be persistent is the lack of alternative sources of energy for domestic activities to replace bio-energy use. This causes almost all households to continue relying on firewood and charcoal (see also [35]). It was observed that coastal forests are still affected by uncontrolled fires, timber extraction, overgrazing, and development of infrastructure same factors studies in many previous years [28]. Unfortunately, these are same activities collectively documented to cause an annual deforestation rate of between 130,000 and 500,000 ha per annum [13] between 1990 and 2010s. The situation is getting worse in the coastal zone, as some of these activities are increasing instead of decreasing. For example, it was reported in this study that overgrazing is currently extensive and contribute to environmental degradation than in 1980s. Grazing leaves the land bare and exposes makes it vulnerable to soil erosion. Each farmer complained about livestock grazing as it not only destroying vegetation, but also water sources and farm crops. Livestock keepers claimed that have migrated from regions such as Arusha, Dodoma and Singida mainland regions to the coastal zones in search for livestock fodder and water. This is a coping strategy following many inland areas being affected by climate change. However, it was discovered that livestock grazing is positively considered an opportunity to reduce fire incidences and spreading because the system doesn't leave grasses to catch up fire.

\subsection{Existing Opportunities for Managing Coastal Forests Ecosystems}

People in the study area suggested starting growing trees for various uses (Figure. 7). The move from natural trees dependence to plantation is because it is now well understood that trees for different uses have declined on public lands. Relying on natural forests limits freedom to use forests trees and other products. Interviewees were open and stated that over-dependence on natural trees creates competition for access and causes conflicts refereeing to Uzigua Forest Reserve current re-mapping and eviction of people. In addition, it was discovered that open access to forest ecosystems on village land is affecting freedom and management plans as noted by [36], that forests occurring on the general lands are rapidly deforested and degraded. An available potential to tree planting is that households own land traditionally and not all the hectares are used for agriculture. Land ownership is between 10-30 hectares per household in average. Villagers consider that if they are facilitated to grow trees, not only they will have assets but also they will be assured with land owner-ships. This consideration is important as a piece of land planted with trees has added value in comparison to one which is bare. It was found that this tree planting is a good opportunity to comply with [37] efforts like what was done in South Africa. Alternatively, people have started a move to construct houses by use of earth bricks. However, if precautions are not taken carefully, this move is opening a new challenge and another pressure to forest loss because more trees will be used in brick burning. Also, individuals feared the issue of water scarcity, especially in summer seasons. Already, there is a water shortage in both villages whereby 20 liters are sold at a price between 500-1 000 Tanzania shillings. This amount of money per given volume of water is not affordable to majority of families. Again, people will have to harvest tree resources so that they can get cash for purchasing water for bricks production and domestic consumption. It is obvious that that suggested alternatives still need services from forests ecosystems, and therefore proper management of the existing forests is unavoidable.

\subsection{Emerging Challenges on Management of CFE}

This study discovered that forests management in the study area is challenging because of the following emerging factors: Persistent food shortage, powered chain saw, motorcycles and water scarcity (see Figure.8).

\subsubsection{Persistent Food Shortage}

For the past three years, farmers didn't get enough food to sustain their families. Heads of the families clearly stated that they continue to rely on forest resources because they don't have sufficient food. To them, food insecurity means lack of maize (Zea mayz), while they might have other foods such as cassava (Mannihot esculentum). People in the study area continued to lack alternative livelihood activities to get bread without depending on agriculture, which contributes to forest degradation. Sesame (Sesamum indicum) production is the leading crop in terms of forest degradation. It is the crop that attracts investors from outside the villages. We found that the use of land within these locations is extensive rather than intensive. For example, there is a perception that sesame must be cultivated in virgin land to break disease and insect pest build up, hence farmers open new farms every season. 
Clearing land for new farm (shifting cultivation) leaves no trees, hence furthering forest degradation. It was noted that poor resource farmers clear new land between 1-5 hectares while more hectares are cleared by the rich investors. The phenomenon of insect build up in sesame production on the same piece of land and under non-shed conditions is hindering intensive agriculture. We call for joint research between foresters and crop researchers to avoid massive loss of forests

\subsubsection{Use of Motorized Chain Saw}

We noticed is that, there are new forces that promote forest degradation now than before. Technology such as use of powered hand saws is used in tree felling in preparing for new farms, charcoal and timber production. Across all ten focus group discussions and individual interviews, it was found that with chain saws, there is a massive production of timber and charcoal compared to previous times when hand saws and axes were used. It takes a few days to produce hundreds and thousands of charcoal bags and pieces of timber and logs by using this technology. An additional threat of this technology is that harvesters cut and use trees of any size.

\subsubsection{Use of Motorcycles for Transportation}

Use of motorcycles, locally known as "bodaboda" is another emerging challenge. Bodaboda are used to transport large quantities of charcoal and timber or another forest resource in a shorter time and from a far and remote distance. "Thanks to motorcycles service providers for transporting forest resources from far away to my homestead, without them, my life could be difficult at Village" says the 65 years old man who sells charcoal in Kwaruhombo village. This transportation is increasing significant threats to forests management because: i. Bodaboda transports forests resources from remote places where it would have been impossible by trucks or humans contrary findings by [38]. At present, timber and charcoal production in remote forest locations is possible provided there are small pathways that facilitate bodaboda passing. ii. Bodaboda men leak information about forest management patrols, hence making monitoring complicated.

\subsubsection{Fresh Water Scarcity}

We found that the current long dry spells affect the movement of people from relying on natural trees to planted ones. People in the study area are willing to engage into tree planting, but they are challenged from drought. This challenge was found to be more complicated especially when people have limited access and low understanding of proper tree planting materials (seed and seedlings). Lack of knowledge on what species of trees can do well in long dry spells is another area which needs interventions. There are few respondents who see that it is rather late to plant trees because the environment is already affected by drought. For example, a village elder man in Kwang'andu states "I see, it is too late now, am old, I can't grow trees because the climate is not conducive, I failed even to get maize harvest for three years consecutively, there is no rain nor irrigation scheme and so I will continue to use the available natural forests trees". It is evident that coastal forest management is challenged from the long term existing factors and the emerging ones. Therefore, there is a need to revise management practices to deal with a wider spectrum of problems beyond those documented by [39].

\section{Conclusions}

Coastal forests continue to play a significant role in proving a wide range of ecosystem services and functions. Coastal communities continued to rely on coastal forests is a result of lacking in livelihood activities which do not depend on forests resources. Because of over dependence on forests resources to meet the daily needs, these forests are pressured to degradation. Degradation and coastal forests services dwindling is well known by local people. Because of shortage in forests services supplied by natural forests, local community is willing to embark in the planting trees to improve the value of land, own trees and hence manage the environment and avoid conflicts over natural forests use. However, awareness of a wide range of coastal forest ecosystem services is lacking and majority of the villagers are not aware about management plans, policies, regulations and implementations strategies. Persistence food shortage, motorized trees harvesting chain saws and motorcycle transportation are the emerging and challenging management issues. Therefore, in order to realize a wider understanding of coastal forest services and their implications on management, it is important to address a full range of services derived from these forests as well as dealing with the emerging challenges. A link between forests management must be linked with biophysical research findings and forest resource users. Researches on the impact of policies, information and education on forest resources sustainability should be carried out to understand how a balance between social and ecological demand would be created for sustainable forests management along the coastal zone of Tanzania.

\section{Acknowledgements}

Thanks to Dr. Tamara Weiss, Masanche Nelson Nkoma and Laura Wangsness Willemsen, University of Minnesota for their comments on the first draft of this article. Special thanks to Prof. Charles Weiss, a distinguished Professor (retired) of Science, Technology and International Affairs School of Foreign Service, Georgetown University for his valuable comments. We value the support we got from the Ministry of Natural Resources and Tourism-United Republic of Tanzania. Thanks to all respondents, field officers and leaders of Mbwewe ward. We thank the College of Forestry, Fujian Agriculture and Forests University-(FAFU) Fuzhou 
in the P.R. China for providing resources that contributed to this successful work.

\section{REFERENCES}

[1] Millennium Ecosystem Assessment, "Ecosystems and human well-being; Synthesis," Island Press, Washington, DC., 2005.

[2] K. R. J. Keenan, G. A. Reamsb, F. Achard, J. V. de Freitas, A. Grainger, and E. Lindquist, "Dynamics of global forest area: Results from the FAO Global Forest Resources Assessment 2015," For. Ecol. Manage., vol. 352, pp. 9-20, 2015.

[3] FAO, "FRA-Global Forest Resources Assessment 2015 Desk reference," Rome Italy, 2015.

[4] S. Sloan and J. A. Sayer, "Forest Ecology and Management Forest Resources Assessment of 2015 shows positive global trends but forest loss and degradation persist in poor tropical countries q," For. Ecol. Manage., vol. 352, pp. 134-145, 2015.

[5] URT, "National Forest Resources Monitoring and Assessment of Tanzania Mainland;Ministry of Natural Resources \& Tourism, Tanzania Forest Services Agency in Collaboration With the Government of Finland and Food and Agriculture Organization (FAO) of the United Nat," Dar es Salaam, Tanzania, 2015.

[6] J. Francis and I. Bryceson, Tanzanian Coastal and Marine Resources: Some Examples Illustrating Questions of Sustainable Use; Dar es Salaam Tanzania. 2001, pp. 76-102.

[7] D. Arthur I.M, "The Cosatal Forests of Tanzania; A national synthesis report for the preparation of WWF- EACFE programme," Dar es Salaam, Tanzania, 2000.

[8] A. Whitney, T. Bayer, J. Daffa, C. Mahika, and J. Tobey, State of the Coast Report 2003: The National ICM Strategy and Prospects for Poverty Reduction. Dar es Salaam, Tanzania: Tanzania Coastal Management Partnership, 2003.

[9] URT, "United Republic of Tanzania National Population and Housing Sensus, National Bureau of Statistics (NBS), Ministry of Fuinance, Dar es Salaam Tanzania.," 2012.

[10] K.M Howell. , Msuya. C.A., Mligo, C., Werema. C, "Biodiversity Surveys of Poorly Known Coastal Forests of Southeastern Tanzania and Zanzibar," Dar es Salaam, Tanzania, 2012.

[11] C. Mligo, "Conservation of plant biodiversity of Namatimbili forest in the southern coastal forests of Tanzania," Int. J. Biodivers. Conserv., vol. 7, no. 3, pp. 148-172, 2015.

[12] UNDP, "Extending the Coastal Forest Protected Area Subsystem in Tanzania:PIMS No: 2760 Proposal ID: 00058855, Project ID: 00073328," Extending Coast. For. area Syst. Tanzania, p. pg.107, 2004.

[13] FAO, "Using spatial information to support decisions on safeguards and multiple benefits for REDD + in Tanzania; A joint report publication between the Ministry of Natural Resources \& Tourism and the UN-REDD Programme, supported by FAO (FAO-Finland Forestry Pro,” 2013.
[14] A. I. M. Dallu, "Workshop on Tropical Secondary Forest Management in Africa: Reality and Perspectives FAO/EC LNV/GTZ in collaboration with ICRAF and CIFOR Nairobi, Kenya, 9-13 December 2002," 2002.

[15] G. . Kajembe, L. Mbwambo, J. Z. Katani, and N. M. Dugilo, "Impacts of Decentralisation of Forest Management: Evidences from Tanzania," pp. 1-12, 2004.

[16] T. Blomley and H. Ramadhani, "Going to scale with Participatory Forest Management: early lessons from Tanzania," Int. For. Rev., vol. 8, no. 1, pp. 93-100, 2006.

[17] A. Agrawal and N. Perrin, "Mobilizing Rural Institutions: A Comparative Study of Rural Institutions for Improving Governance and Development: Afghanistan, Ethiopia, India, Vietnam, and Yemen," Gov. An Int. J. Policy Adm., no. 114, p. 91, 2009.

[18] URT, "Sustainable Forest Management in a Changing Climate, FAO-Finland Forestry Programme- Tanzania; A fire Baseline for Tanzania.," Dar es Salaam, Tanzania, 2013.

[19] C. Mligo, "Conservation of Plant Species Diversity Based on Richness and Evenness Criteria in the Coastal Forests of Tanzania," vol. 6, no. 1, pp. 1-20, 2015.

[20] G. R. E. and T. R. J. D. Lovett C.J, Ruffo, C.K, Lovett C.J, Ruffo, C.K, Gereau R.E. and Taplin R.J.D. (2006). Field Guide to the Moist Forest Trees of Tanzania. Centre for Ecology, Law and Policy; Frontier Tanzania; York Publising Services Ltd UK., 2006.

[21] C. H. Greenberg and B. S. Collins, Natural Disturbances and Historic Range of Variation; Type, Frequency, Severity, and Post- disturbance Structure in Central Hardwood Forests USA: Managing Forest Ecosystems, vol. 32. Springer International Publishing Switzerland, 2016.

[22] F. Bravo, V. LeMay, R. Jandl, and K. von Gadow, Managing Forest Ecosystems: The Challenge of Climate Change, Volume 17., vol. 53, no. 9. Springer Science + Business Media, B.V., 2013.

[23] D. J. G. Emmanuel N. Chidumayo, The Dry Forests and Woodlands of Africa;Managing for Products and Services. Washington DC, USA: Earthscan Ltd, 2010.

[24] M. G. Turner, D. C. Donato, and W. H. Romme, "Consequences of spatial heterogeneity for ecosystem services in changing forest landscapes: Priorities for future research," Landsc. Ecol., vol. 28, no. 6, pp. 1081-1097, 2013.

[25] L. Gajdzik, A. Vanreusel, N. Koedam, J. Reubens, and A. W. N. Muthumbi, "The mangrove forests as nursery habitats for the ichthyofauna of Mida Creek (Kenya, East Africa)," J. Mar. Biol. Assoc. United Kingdom, vol. 94, no. 5, pp. 865-877, 2014.

[26] A. Younge, G. Negussie, and N. Burgess, "Eastern Africa Coastal Forest Programme: WWF-EARPO Regional Workshop Report Nairobi. February 4-7 2002," in Workshop Report, Nairobi February 4-7 2002, 2002.

[27] K. S. S. Nair, Tropical Forest Insect Pests: Ecology, Impact, and Management. 2007.

[28] P. Njoroge, P. Ndang'anga, Kariuki, R. Owako, F. Munyekenye, N. Kyonjola, and M. Kariuki, "Biodiversity Status and Trends Report for the Eastern Arc Mountains and 
Coastal Forests of Kenya and Tanzania Region, 2012," Nairobi, Kenya, 2012.

[29] A. Namara and X. Nsabagasani, "Decentralization and Wildlife Management: Devolving Rights or Shedding Responsibility? Bwindi Impenetrable National Park, Uganda: Environmental Governance in Africa," 2003.

[30] D. Roe, F. Nelson, and C. Sandbrook, "Community management of natural resources in Africa Impacts experiences and future directions Community management of natural resources in Africa Impacts , experiences and future directions," 2009.

[31] R. S. De Groot, J. Blignaut, S. Van Der Ploeg, J. Aronson, T. Elmqvist, and J. Farley, "Benefits of Investing in Ecosystem Restoration," Conserv. Biol., vol. 27, no. 6, pp. 1286-1293, 2013.

[32] NEMC, "Integrated Ecosystems Assessment in Tanzania :A Report on Experiences in Ecosystems Management," Dar es Salaam, Tanzania, 2006.

[33] Y. Pan, R. A. Birdsey, O. L. Phillips, and R. B. Jackson, "The Structure, Distribution, and Biomass of the World's Forests,"
Annu. Rev. Ecol. Evol. Syst., vol. 44, no. 1, pp. 593-622, 2013.

[34] R. A. Kitula, M. Larwanou, P. T. K. Munishi, J. I. Muoghalu, and L. Popoola, "Climate vulnerability of biophysical systems in different forest types and coastal wetlands in Africa : a synthesis," Int. For. Rev., vol. 17, pp. 67-77, 2015.

[35] TFCG, "Special Edition on Tanzania's Coastal forests; Where are Tanzania's Coastal Forests and Why are They Important:," Arc Journal, Dar es Salaam, Tanzania, vol. ISSN NO 08, no. 28, p.pg 32, 2013.

[36] J. Abdallah and G. . Monela, "Overview of Miombo woodlands in Tanzania," Morogoro, Tanzania, 2007.

[37] IUCN, "Working for Conservation Programme Report 2006," Rue Mauverney 281196 Gland Switzerland, 2006.

[38] R. . Malimbwi and E. Zahabu, "The analysis of sustainable charcoal production systems in Tanzania," FAO Criteria Indic. Sustain. woodfuels, pp. 229-261, 2009.

[39] B. P. Hooper, "Integrated water resources management and river basin governance," J. Contemp. Water Res. Educ., vol. 1, no. 126 , pp. 12-20, 2011. 